\title{
You are Kind, you are Smart, you are Important: the Linkages between Individual Factors and the Intention to Repatriate among Malaysian Self-Initiated Expatriates
}

\author{
*Siti Fatimah1, Yusliza², Lilis Surienty² \\ ${ }^{1}$ Universiti Teknologi MARA, Malaysia \\ 2Universiti Sains Malaysia, Malaysia \\ *fatimah.zakaria88@gmail.com
}

\begin{abstract}
Brain drain' is a terminology used to describe the migration of people endowed with a high level of human capital. Countries, a developing such as Malaysia, consider this to be a detrimental effect to the country's growth with the outflow movement of their talented professionals. Problems seem to increase when these individual have silo mentalities regarding their home countries' development when they show limited number of return. Thus, there is a need to study the determinants of the intention to repatriate among these talented professionals. In addition, it becomes a more interesting study when it is directed to the selfinitiated expatriates who determine their own outgoing and incoming. The development of the proposed model would be in line with the Malaysian government efforts to attract the talented professionals to serve their home country. The theoretical framework for this study consists of factors from the individual perspective and their relationships with the intention to repatriate. The Theory of Reasoned Action developed by Fishbein seems to be the appropriate theory to be applied in this study explaining factors to determine intention. This paper concentrates more on conceptualizing the relationship between individual's factors and the intention to repatriate among the self-initiated expatriates. Based on a review of extent literature on self-initiated expatriates and the intention to repatriate, a model is presented and propositions outlined for future empirical testing.
\end{abstract}

Keywords: Individual factors, intention to repatriate, self-initiated expatriate, brain drain, Malaysia

\section{Introduction}

"Malaysians are resilient people who can thrive anywhere in the world, whether as students or in trade. This is perhaps a reflection of who we are and our heritage as a maritime, sojourning people since the time of the Malaccan Empire." (Datuk Mustafa Kamal, International Trade and Industry Minister, the Star Online, March 16, 2012). Historically, people have the urge to travel with a concrete and commonality aims to improve their standards of living. This shows that having the sense of internationalization is not a new phenomenon since it has begun from the early days. Indeed having a global perspective mindset is a good thing. As for that, more and more people are moving towards working in more global arena, which is a good thing. However, the negative side is that, these people who are moving abroad, especially the talented and professionals with high values of human resource assets tend to forget about the needs for them to return to their home countries. These indeed create panicking on the side of the country as increasing number of 'brains' are draining out of the country. Table 1 indicates the size of Malaysian brain drain by country of destination from 2000 until 2010. Clearly from the table it shows that most of the Malaysian brains are in Singapore with 55, 210 total number of increase from year 2000 until 2010, besides Australia, United States, United Kingdom and other developed countries. It shows that the number of brain drain increases over years. As to avoid shortfalls of professionals and labour, a country needs to invest more money to welcome foreign professionals to help the country boosting up the economy instead of having the chance to use Malaysian own professionals.

The outbound movement of professionals from a developing country constitutes a significant loss for the developing country in terms of economic growth and development. Losing such qualified and skilled workforce will bring difficulties for the home country in achieving high per capita income thus undermining the economic development. Indeed individuals flying abroad to have an international experience, to increase their knowledge level, to improve their network relationships and other beneficial factors. However, problems seem to increase when these individual have silo mentalities regarding their home countries' 
development. Because of this, there is a need to study the determinants of the intention to repatriate among these talented professionals.

Table 1: The size of Malaysian brain drain by country of destination, 2000-2010

\begin{tabular}{lll}
\hline & Brain Drain & \\
& 2000 & 2010 \\
\hline Balanced sample total & 184,014 & 276,558 \\
Singapore (residents only) & 66,452 & 121,662 \\
Australia & 38,620 & 51,556 \\
United States & 24,085 & 34,045 \\
United Kingdom & 12,898 & 16,609 \\
Canada & 12,170 & 12,807 \\
Brunei & 6,438 & 10,208 \\
New Zealand & 4,221 & 6,708 \\
Other countries & 19,130 & 22,962 \\
\hline
\end{tabular}

Gaps of the Study: Research in area of expatriation has put high focus on organizationally initiated expatriates and vaguely focused on the self-initiated expatriates. Comparative studies have distinguished the different between the self-initiated expatriates and company-backed expatriates, which involve categories of factors such as demographics, employer and task variables, motives, repatriation and future career and compensation (Suutari \& Brewster, 2000). Ren, Bolino, Shaffer and Kraimer (2012) summarizes the research that has been conducted on organizationally initiated expatriates such as Repatriate Adjustment, (e.g., Lee \& Maure, 1997), Organizational Support Practices, (e.g., Lidgard \& Gilson, 2002) and eventually Repatriate Turnover Intentions, (e.g., Sanchez, Spector \& Cooper, 2000). A self-initiated expatriate on the other hand is a more recent new term, which is still in the early stages of literature development. The majority of the research on this topic has been conducted in Western countries like Australia, Europe, Finland, France and others. However, very few articles have focused on Malaysia (Choong, Keh, Tan, Lim \& Toh, 1990; Junaimah \& Yusliza, 2011; Junaimah, Yusliza \& Khoo, 2009; Yusliza, 2011). The literature available on the topic of selfinitiated expatriates is still lacking and requires more attention especially in area relating to determine their intention to repatriate. This research will focus on the individual factors that contribute to the development of the intention to repatriate among Malaysian self-initiated expatriates. The current research needs more study to understand clearly the motivation that lies within these individuals that attracts them to return to their home country, which is Malaysia. The development of this model would be in line with the Malaysian government efforts to attract the talented professionals to serve their home country.

\section{Conceptual Understanding}

Brain Drain: The formation of this study begins with the arrivals of the brain drain issues banging all over media trying to find solution for the problem of talent shortages. Scholars then began to define the term brain drain in order to fully understand the issues arouse all over the world especially the developing countries like China, India and Malaysia which received high impact for loosing such talented skills. The "Brain" which is the most amazing, elegant and complex structure in the universe, refers to a skill, competency or attribute that is seen as a potential asset in a human. "Drain" in this context implies the fast movement of professionals out of the home country at a higher level than that which might be desired (Davenport, 2004). Linking the two words implies the departure of the most talented away from their home country (Bushnell \& Choy, 2001). Barker (2003) define brain drain as not only the loss of talent but specifically focus on the reducing number of scientific, technical and leadership talent that conceived high value for the nation to develop. Other scholars suggest that it is so called brain drain when there is an increasing outflow of high-skills individuals, with an academic or professional degree beyond high school (Beine, Docquier \& Rapoport, 2001). Therefore, it is important for the country to take good provision on the movement of their highly talented and professionals in order to assure that these talented will have the guts to serve their countries after gaining such tremendous experience abroad. 
Self-Initiated Expatriates: It has become a common trend for an individual to fly in and out of a country for many reasons such as employment, career prospect, travelling purpose or maybe because of lifestyle attraction. People tend to speculate that these individuals are sent by their company for purpose of the development of an organization. Indeed some of the individuals are sent by the organization, however, there are also independent individual who initiate themselves to fly in and out of a country for same reason but these individuals seems to have little attention (Inkson, Arthur, Pringle \& Barry, 1997; Doherty, 2012). The formation of the so called 'self-initiated' begin in 1997 when scholars like Inkson and some of his colleagues manage to come up with the term 'Overseas Experience' (OE) to symbolize these type of individuals. Inkson et al. (1997) describe individuals who undertake Overseas Experience based on certain characteristic including the source of initiation which must be from the individual itself decided to go abroad using his/her own personal savings or funding with personally oriented development and career goals. In year 2000, Suutari and Brewster argue within their context that it is best to describe these types of individual as 'Self-Initiated Foreign Work Experienced' (SIE). These individuals are also known as a long term individually-initiated, which travel to other countries in order to pursue their development experiences in terms of personal, career and cultural. Suutari and Brewster suggest that it is more appropriate to use the word 'foreign' instead of 'overseas' that may not be suitable to apply for those travelling within Europe. In 2005, Myers and Pringle conducted a study using sample from New Zealand; argue that their investigation is more on a global context and therefore applying the term 'Self-Initiated Foreign Experience' (SIE) in line with Suutari and Brewster. These individuals are also categorized as 'Self-Managed International Career' because of the nature of flying abroad and searching for new career abroad is done initially by the individuals themselves.

Not long after, Jokinen, Brewster and Suutari (2008) explores the career capital of expatriates, comparing the usual company assigned expatriate (AE) with the 'Self-Initiated Expatriate' (SE). In their research, they use the term 'self-initiated expatriate' to describe the professionals who manage to find new job in host country at their own cost. This study uses 200 Finnish expatriates and found considerable similarities and differences in the development of career capital within AE and SE. In 2009, Thorn come up with a study using 2,600 internet survey responses from highly educated New Zealanders living and working around the world. In their study, they used the term 'self-initiated mobility' to symbolize the highly educated individual circulating between countries who self-initiate their own movement. Most of the literatures recently exploring these independent professionals working abroad are using the term 'self-initiated expatriates' (Doherty, 2012; Tharenou \& Caulfield, 2010; De Cieri, Sheehan, Costa, Fenwick \& Cooper, 2009). In this study, the researcher will use the term 'self-initiated expatriates' to symbolize the Malaysian professionals who are currently working abroad. On top of that, these professionals should be someone who is flying abroad using their own pocket money regardless whether they are supported by their own family or close related friends as long as they are not sent to work outside countries by multinational companies (Lee, 2005; Bhuian, Al-Shammari and Jefri, 2001). By all means, these professionals are self-financing their journey before departure from their home country up to the extent of finding their own job when they have reached host country. As they are selfinitiating their own journey, often there would be no specific time frame in mind for these professionals on deciding when to return. The major purpose considered by these self-initiated expatriates to fly away from home country highly focused on their personal and career development. Again, this study intent to search for answers in determining the intention to repatriate back to Malaysia among self-initiated expatriates who are currently working abroad.

\section{Dependent Variable}

Intention: It is narrated on the authority of Umar ibn Al-Khattab who said: I heard the messenger of God say: "All actions are judged by motives, and each person will be rewarded according to their intention."

(Saheeh Al-Bukhari, Saheeh Muslim)

The above statement portrays that every action or behavior taken part in by a human begins with the creation of intention circling around his head. When a man says 'I am going to do such-and-such', we should say that this was an expression of intention (Anscombe, 1957). Anscombe (1957) describe intention as "the description or expression of a present state of mind, a state which has the properties to characterize it as an intention." Dulany, in his Theory of Propositional Control, has argued that a person should do what he intends or tries to do and claim that intention will lead the person to response (Fishbein \& Ajzen, 1975). In 1967, Fishbein extended Dulany's theory and defined the term intention as the psychological probability that a 
person will implement a certain action (Fishbein \& Ajzen, 1975). Behavioral intention therefore refers to the psychological probability that a person will perform some behavior that he has intended. The formation of intention within an individual begins with the creation of belief and the person's attitude towards that belief. Once the intention has been developed, the probability of the actual behavior taking place is probable. Therefore, intention can be considered as a plan that an individual intends to become an action. The formation of intention within individuals comes from various factors stated by previous researchers. As presented by Fishbein in the Theory of Reason Action, there are two ways to determine intention. First, intention can be developed based on a personal or known as attitudinal factor shown by the individuals to derive such an intention. This means that the way the individual ought to think about certain object makes it come to belief about the object and hence the attitude implied by the individuals will then slowly change and having the intention to perform some behavior on the given object.

Second, the theory suggested that social or normative factor also have the ability to influence the creation of intention within individuals. Normative referent refers to individuals or groups which the individuals are comfortable to share their thoughts about particular subject. However, as for the current study, the focus would be on the individual factors that cause the intention to develop. This would highlight only the attitude shown by the individuals to determine their intention to repatriate back to Malaysia. When it comes to a study that involves intention and behavior of a human being, most of the literature previously used the TRA in order to support their study (Al-Waqfi, 2012). Hence, the researcher find out that, it is suitable to use TRA for the current study. According to the TRA, intention is the critical determinant of behavior. However, Fishbein and Ajzen realized that the action could also remain as the intention. Thus, the actual behavior will depend on what an individual decides for himself. Individual tend to have stronger intention when the behavior in question is believed to be achievable (Bandura, 1977). Therefore, the theoretical framework for this study used the conceptual framework proposes by Fishbein in 1967 as its conceptual underpinning in order to explain the relationships in this study.

Intention to Repatriate: Intention to repatriate exists when professionals either have the courage or are motivated to return to their home country after spending years and years abroad (Lidgard \& Gilson, 2002). Goel, Johnson, Junglas and Ives (2011) described intention to return as the idea of returning to their home country after having such an expatriate experience. Tuan (1977:3) mentioned in his book that "place is security and space is freedom" which explained that humans might be attached or working in some place away from their home country but in the end humans long to return to their own home countries. Thus, intention to repatriate happens when professionals have undergone a series of thoughts about visiting or going back to their home country after spending a significant number of years in other countries. As the saying goes "there is no place like home." Intention can be gained from the personal or attitudinal factors and also from the social norms or persons who have close relation with the individuals that makes the intention (Fishbein \& Ajzen, 1975). To identify the intention to return among the self-initiated, increased focus should be placed on the factors that attract professionals. As for the current study, individual factors will represent the factors from the individual own perspective that motivates the creation of the intention. Individual factors is in line with the attitudinal factor as supported by Fishbein and Ajzen (1975) as the consideration of the existence of intention comes from the individual itself to repatriate back to the home country. As previously has been discussed by Baruch et al., (2007) and Junaimah and Yusliza (2011), the focus has been on the push factors (i.e., career dissatisfaction, family support and quality of work life) and pull factors (i.e., better perks, adjustment process to the host country and greater job opportunities) that lead professionals to move from their home country to a host country. In this current study, the researcher will study the individual factors that have initiated the intention to return to Malaysia among self-initiated Malaysian professionals.

\section{Independent Variable}

\section{Individual Factors}

National Identity: In an article prepared by Tharenou (2010), the author clearly discussed on the issues of identity and how it is related to the mobility of professionals who initiate expatriation. In general, the word 'national' produce an understanding of an individual's citizenship of a particular country. Identity on the other hand refers to a set of characteristics which is broad in nature composing a set of expectations (Simon, 1992, cited in Terry et al., 1999) he or she plays to represent them as belonging to one nation. Tajfel and 
Turner (1979) who developed the Social Identity Theory put forward that people see themselves as not only depend on personal identity but also as belonging to a group or social identity. Social identity reflects the need of an individual to be part of one nation. From the literature of organizational identity propose by Dutton, Dukerich and Harquail (1994), the authors argue that a person is strongly identified with an organization when (1) their identity as an organization member is more prominent than other available identities, and (2) their self-concept has similar characteristics as how they define the organization as a social group. In the case of the current study, the researcher argues that national symbolize as an organization that represents as a certain country. Social identity theory presented by Tajfel and Turner (1979) pointed out that individual construe themselves as belonging to a membership of a social group tend to have some sort of emotional and value which they perceived as important to them. A person sees themselves as belonging to a group of membership whether it is within the scope of a small scale group (e.g., a professional associations) or a larger scale group (e.g., a home-country national) (Tharenou, 2010). Therefore, national identity is a degree to which a member sees themselves as having the same characteristics that they believes define them as within a nation.

Different eras constitute different views on identity. In late 90 's, person is said to hold a core identity for his entire life (Hall, 1999, cited in Kohonen, 2005). Rejecting the believes of holding on to a stable identity, researchers argues that individuals may hold more than one identity to suites their surroundings and this will be an ongoing process (De Cieri et al., 2009; Kohonen, 2005; Sveningsson \& Alvesson, 2003; Lindgren \& Wahlin, 2001). In this current era of globalization with various identity options, people are continuously searching for their identities (Kohonen, 2005). As in the case of an expatriate world, it is their nature to fly in and out of one country that requires them to adjust in number of ways, including their identity (Sanchez, Spector \& Cooper, 2000). Inkson and Myers (2003) mention in their study that OE travelers sense of identity and their concern for ageing relatives back home constantly induce the desire to return among expatriates. However, changing their identity does not mean an entire alteration of one basic identity. This means, the basic identity will not change the individual to be away from one national identity (Kohonen, 2005).

Lifestyle Influence: Benson and O'Reilly are among the scholars who have been actively written number of articles stressing on issues of lifestyle migration. The clear-cut definition of lifestyle migration the researcher found to date refers to affluent individuals regardless of age, moving to places either for short term or long term for various reasons with an ultimate goal of reaching a better quality of life (Benson \& O'Reilly, 2009). To the best of the researcher's knowledge, the key point in this context would be to search for the best quality of life. Narrow into the scope of the present study, again the focus of this study is on determining the intention to repatriate among the self-initiated expatriates. Therefore, the accurate definition of lifestyle taken for this study refers to a sense of believe holds by the expatriates that repatriation to their home country will provide lifestyle benefits for their long term living (Thareno \& Caulfield, 2010). The question in line would be how is it possible that lifestyle has an influence over creating a mindset of having the intention to repatriate among the self-initiated expatriates. Often being heard, one of the factors that pull the expatriate to move abroad is due to the lifestyle factor (Selmer \& Lauring, 2010). Richardson \& Mallon (2005) supported by Selmer \& Lauring (2010) are among the authors that argues expatriation was made to improve their life from boredom with their home country. This means, these expatriates shows that they are more onto being as transmigrants (Torkington, 2010) as having more than one place of residence in which their life involves activities and networking across national boundaries. Hence, it shows that expatriates with a sense of 'adventurous' would be more willing to move from one country to another in search for more exciting lifestyle as the way they want it to be.

On the other side, lifestyle also has been claim by several authors to have influence over the decision to repatriate back to their home country (Inkson, Carr, Edwards, Hooks, Jackson, Thorn \& Allfree, 2004; De Cieri et al., 2009; Mak, 1997; Tharenou \& Caulfield, 2010). Inkson et al., 2004 provide an interesting result from their study whereby lifestyle is among the high ranked factor that indicates the intention to repatriate among these expatriates. In addition to that, lifestyle has been supported by Tharenou \& Caulfield (2010) to explain voluntary return made by these self-initiated expatriates that linked with greater intention to repatriate. Previously, the researcher repeatedly uses the word lifestyle to link with the intention to repatriate. The question would be in terms of what lifestyle that can create such an intention. The paragraphs below will further discuss on how lifestyle can create the intention to repatriate among self-initiated expatriates. It is 
common to say that every expatriates flying out of their own country must have the sense of hoping for the highest rank of safety and security. Selmer and Lauring (2010) added that when it comes to safety and security, women will put more concern as compared to men. Author like Cerdin \& Le Pargneux (2010) describe individuals concern with security or lifestyle as not having the desire for geographical mobility which by all means rarely suits neither assign expatriates nor self-initiated expatriates. Yes indeed, these expatriates especially the self-initiated expatriates are more towards diving into risk taking activities but the issues of security while abroad will still be considered. When the expatriates lean towards a belief that repatriation will provide positive outcomes of the home country lifestyle (Tharenou \& Caulfield, 2010) the intention to repatriate will come to exist.

Besides safer environment of living, climate also plays a role on deciding on the best place to live. Sriskandarajah and Drew (2006) clearly classified four factors that motivate people to move which are family ties, lifestyle, overseas adventure and work. Within the scope of lifestyle motivation, better climate seems to be one of the reasons for moving. From here, it shows that on choosing for the best quality of life preferred by the expatriates, there are certain criteria to seek after for purpose of long term living. As for that, when the Malaysian self-initiated expatriates perceived that Malaysia which are located on the tropical rain forest climate can provide an amenable climate with plenty of sunshine and year round warmer temperatures (Torkington, 2010), the creation of intention to repatriate back to Malaysia would be something for them to ponder. Inevitably, lifestyle is said to have influence on both the intention to stay abroad and also the intention to repatriate. As for the current study, the researcher argues that lifestyle will have an influence over the self-initiated Malaysian expatriates to have the intention to repatriate back to Malaysia.

Individual Shock Event: Literatures in area of 'shock' in the context of international business or human resources seem to be bias in terms of 'cultural shock' rather than more general types of shock faces by the expatriate (Black \& Gregersen, 1991; Lyon, 2002). Yes indeed some of the expatriates will have more tendencies towards experiencing shock when entering other countries but not necessarily must it be cultural shock. Especially when it comes to literature on self-initiated expatriates, the researcher found out that cultural shock are not an issue that requires lengthy amount of time to discuss. The researcher found out that expatriates who are flying abroad at their own course and financial support which is better known as selfinitiated expatriates tend to have fewer problems in terms of adapting into new places. Therefore, as for this study, the researcher will focus on the shock events as in general which the individual faces that cause them to have the intention to repatriate back to their home country. Before going any further, the researcher will now discuss the term shock event in this current study context. Shock event is a jarring event either expected or unexpected that requires an individual to involve in a sudden alteration (Lee \& Maurer, 1997; Kulik, Treuren \& Bordia, 2012; Lee \& Mitchell, 1991). The formulation of this noticeable event will then initiate mental consideration within targeted individual to create numbers of intentions to make a change decision. Most of the shock event occurs tend to shake individuals current position that ought them to take prompt option. Literature on shock event frequently is found on area of employee turnover caused by shock event (Lee \& Mitchell, 1991; Lee \& Maurer, 1997; Kulik, Treuren \& Bordia, 2012). As for this study, the researcher adapts the construct from the explanation proposed for quitting a job to quitting a host country to repatriate that specifically focus on shock event. Therefore, the current study argues that individual shock event might be one of the factors that can cause the self-initiated expatriate to have the intention to repatriate back to Malaysia.

\section{The Proposed Model}

From the previous discussion on the determinant of the intention, Theory of Reason Action is used to develop the proposed framework for this study. Figure 1 demonstrates the proposed research model that investigates the relationship between individual factors (national identity, lifestyle influential and individual shock event) and intention to repatriate. 
Figure 1: A Research Model

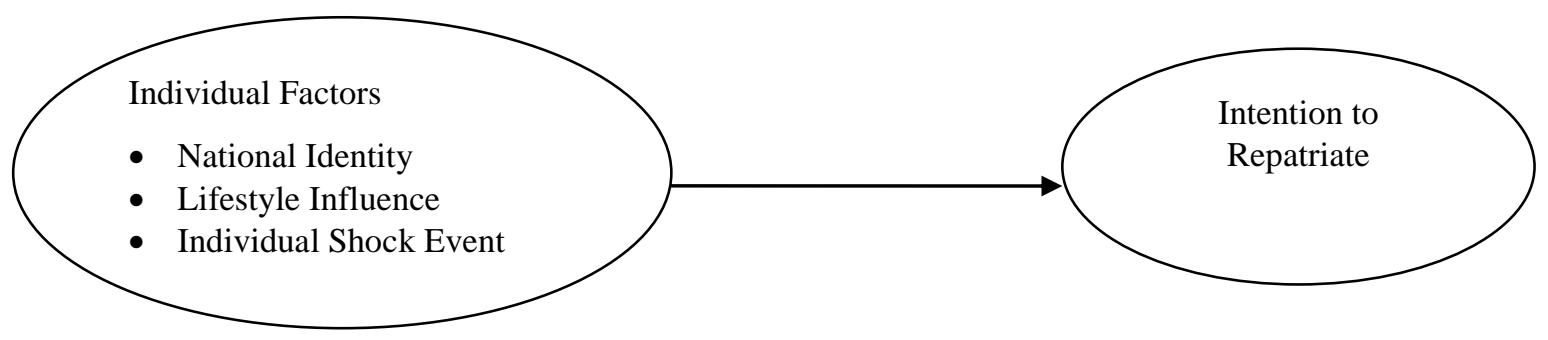

Individual Factors and the Intention to Repatriate: Individual factors include factors from the perspective of the self-initiated expatriates itself that creates the intention to repatriate. This is in line with the Theory of Reason Action developed by Fishbein stating that one of the factors that can bring an individual on having such an intention is the individuals own attitude. The creation of attitude within individuals comes from the beliefs they hold on to. In this context, the beliefs of holding on to one own national identity and lifestyle is said to have a link with the intention to repatriate. Shock event either negative or positive faces by the individual can also create the intention to repatriate among self-initiated expatriates. Hence, the overall proposition of the relationship between individual factors and the intention to repatriate can be advanced.

Proposition 1 : Individual factors influence the creation of intention to repatriate among the self-initiated Malaysian expatriates.

Once believe as belonging to one nation managed to be embedded within the expatriates, the tendency to have such an intention to repatriate is there (Thraenou, 2010). National identity is said to have a concrete reason that causes expatriates to return back to their home countries (Tharenou, 2010; De Cieri et al., 2009; Tharenou \& Caulfield; 2010). It's the nature of the expatriates work to go and work outside their home countries that makes them experience various identities. Regardless of the matter, expatriates with a sense of strong beliefs on their national identity will develop positive feelings as being a citizen of their home country (Tharenou \& Caulfield, 2010). Previous studies conducted using sample of Australian professionals have pointed out that $53.5 \%$ of the skilled self-initiated expatriates have the intention to repatriate because of national identity (De Cieri et al., 2009). Hence, the following proposition is postulate:

Proposition $1 a$ : National Identity influences the creation of intention to repatriate among the self-initiated Malaysian expatriates.

Lifestyle has also been claim by several authors to have influence over the decision to repatriate back to their home country (Inkson et al., 2004; De Cieri et al., 2009; Mak, 1997; Tharenou \& Caulfield, 2010). Inkson et al., 2004 provide an interesting result from their study whereby lifestyle is among the high ranked factor that indicates the intention to repatriate among these expatriates. In addition to that, lifestyle has been supported by Tharenou \& Caulfield (2010) to explain voluntary return made by these self-initiated expatriates that linked with greater intention to repatriate. Safer lifestyle environment and comfortable climate is said to be the most preferable among the expatriates. Therefore, the following proposition can be stated:

Proposition $1 b \quad$ : Lifestyle influences the creation of intention to repatriate among the self-initiated Malaysian expatriates.

Shock event experience by the individuals seems to be one of the factors that create the feeling of not continuing to stay abroad. Decision made by an expatriates involving quitting a host country rises from either expected or unexpected event that create dissatisfaction for the expatriates (Tharenou \& Caulfield, 2010). Dissatisfaction might come from the workplace, surrounding environments or other among the committee in the host country. Logically, dissatisfaction will cause the expatriate to feel unhappy and therefore leads to stress. According to Al Waqfi (2012), stress and uncertainty encountered during expatriation experience might be a determining factor that causes the creation of intention to leave the country. Hence, he following proposition is propose:

Proposition 1c : Individual Shock Event influences the creation of intention to repatriate among the selfinitiated Malaysian expatriates. 


\section{Conclusion}

This paper synthesizes a diverse body of literature on the determinant factor of having the intention to repatriate among the self-initiated expatriates. This area of study is slightly a new area that requires continuance study in order to fill in the gaps. This paper tries to describe in details the definition of selfinitiated expatriates differentiating it from company backed expatriates. Numbers of study has been found in area of company backed expatriates and still on the process of increasing the publication of studies in area of self-initiated expatriates. As in line with the issues of brain drain, there is a need to study on the factors that can create the thoughts of repatriating back to the home country like Malaysia. Repatriation of the selfinitiated expatriates with full of global knowledge is seems as one of the important assets requires to help Malaysia boosting up the economy.

Acknowledgments: The funding for this study was supported in part by an Incentive Postgraduate Research Grant (1001/PMGT/822209) from Universiti Sains Malaysia.

\section{References}

Al-Waqfi, M. A. (2012). The Antecedents and Outcomes of Expatriate. Human Resource Management, 8(4), 434-465.

Anscombe, G. $\quad$ E. $\quad$ M. (1957). Intention. Retrieved from http://books.google.com.my/books?hl=en\&lr=\&id=_D1xjNXFT8cC\&oi=fnd\&pg=PR7\&dq=anscombe\& ots=NP-90zKw-R\&sig=MjGOy9_C1dBKXfREeNe4v0zXQPg.

Bandura, A. (1977). Self-efficacy: toward a unifying theory of behavioral change. Psychological Review, 84(2), 191.

Barker, R. L. (2003). The social work dictionary (5th Ed.). Washington, DC: NASW Press.

Baruch, Y., Budhwar, P. S. \& Khatri, N. (2007). Brain drain: Inclination to stay abroad after studies. Journal of World Business, 42(1), 99-112.

Beine, M., Docquier, F. \& Rapoport, H. (2001). Brain drain and economic growth: theory and evidence. Journal of Development Economics, 64(1), 275-289.

Benson, M. \& O'reilly, K. (2009). Migration and the search for a better way of life: a critical exploration of lifestyle migration. The Sociological Review, 57(4), 608-625.

Bhuian, S. N., Al-shammari, E. S. \& Jefri, O. A. (2001). Work-related attitudes and job characteristics of expatriates in Saudi Arabia. Thunderbird International Business Review, 43(1), 21-32.

Black, J. S. \& Gregersen, H. B. (1991). Antecedents to cross-cultural adjustment for expatriates in Pacific Rim assignments. Human Relations, 44(5), 497-515.

Bushnell, P. \& Choy, W. K. (2001). Go west, young man, go west!? Treasury working paper 01/07 (Treasury Wellington) (pp. 1-23).

Cerdin, J. L. \& Pargneux, M. L. (2010). Career anchors: A comparison between organization-assigned and self-initiated expatriates. Thunderbird International Business Review, 52(4), 287-299.

Choong, Y. O., Keh, C. G., Tan, Y. T., Lim, Y. H. \& Tho, M. S. (1990). Propensity to work abroad amongst generation Y working adults in Malaysia. Diaspora, 2000, 2010.

Davenport, S. (2004). Panic and panacea: brain drain and science and technology human capital policy. Research Policy, 33(4), 617-630.

De Cieri, H., Sheehan, C., Costa, C., Fenwick, M. \& Cooper, B. K. (2009). International talent flow and intention to repatriate: An identity explanation. Human Resource Development International, 12(3), 243-261.

Doherty, N. (2012). Understanding the self-initiated expatriate : A review and directions for future research. International Journal of Management Reviews, 15(4)

Dutton, J. E., Dukerich, J. M. \& Harquail, C. V. (1994). Organizational images and member identification. Administrative science quarterly, 239-263.

Fishbein, M. \& Ajzen, I. (1975). Belief, attitude, intention and behaviour: An introduction to theory and research. (D. C. Park \& L. L. Liu, Eds.) Reading MA Addison Wesley (p. 480). Addison-Wesley. Retrieved from http://www.people.umass.edu/aizen/f\&a1975.html.

Goel, L., Johnson, N. A., Junglas, I. \& Ives, B. (2011). From space to place. Predicting users' intentions to return to virtual worlds, 35(3), 749-771. 
Inkson, K., Arthur, M. B., Pringle, J. \& Barry, S. (1997). Overseas experience: Contrasting models of international human resource development. Journal of World Business, 32(4), 351-368.

Inkson, K., Carr, S., Edwards, M., Hooks, J., Jackson, D., Thorn, K. \& Allfree, N. (2004). From brain drain to talent flow: Views of Kiwi expatriates. University of Auckland Business Review, 6(2), 29-39.

Inkson, K. \& Myers, B. A. (2003). The big OE: self-directed travel and career development. Career Development International, 8(4), 170-181.

Jokinen, T., Brewster, C. \& Suutari, V. (2008). Career capital during international work experiences: Contrasting self-initiated expatriate experiences and assigned expatriation. The International Journal of Human Resource Management, 19(6), 979-998.

Junaimah, J. \& Yusliza, M. Y. (2011). Brain Drain: Propensity to Leave by Malaysian Professionals. International Journal of Innovation, Management and Technology, 2(2), 119-122.

Junaimah, J., Yusliza, M. Y. \& Khoo, M. Y. (2009, October). Factors that drive brain drain of accountants in Malaysia. Proceedings of the 6th International Conference on Intellectual Capital, Knowledge Management \& Organizational Learning, School of Information Studies, McGill University, 1-2 October, Montreal, Canada (pp. 164-76). Pearson Education.

Kohonen, E. (2005). Developing global leaders through international assignments: An identity construction perspective. Personnel Review, 34(1), 22-36.

Kulik, C. T., Treuren, G. \& Bordia, P. (2012). Shocks and final straws: Using exit-interview data to examine the unfolding model's decision paths. Human Resource Management, 51(1), 25-46.

Lee, C. H. (2005). A study of underemployment among self-initiated expatriates. Journal of World Business, 40(2), 172-187.

Lee, T. W. \& Maurer, S. D. (1997). The Retention of Knowledge Workers with the Unfolding Model of Voluntary Turnover. Human Resource Management Review, 7(3), 247-275.

Lee, T. W. \& Mitchell, T. R. (1991). The unfolding effects of organizational commitment and anticipated job satisfaction on voluntary employee turnover. Motivation and Emotion, 15(1), 99-121.

Lidgard, J. \& Gilson, C. (2002). Return migration of New Zealanders: Shuttle and circular migrants. New Zealand Population Review, 28(1), 99-128.

Lindgren, M. \& Wåhlin, N. (2001). Identity construction among boundary-crossing individuals. Scandinavian Journal of Management, 17(3), 357-377.

Lyon, C. R. (2002). Trigger event meets culture shock: Linking the literature of transformative learning theory and cross-cultural adaptation. Proceedings of the 43rd Annual Adult Education Research Conference (pp. 237-242). Raleigh, NC: North Carolina State University.

Mak, A. S. (1997). Skilled Hong Kong immigrants' intention to repatriate. Asian and Pacific Migration Journal, 6, 169-184.

Malaysia Economic Monitor. (2011). Brain Drain, (April). The World Bank.

Myers, B. \& Pringle, J. K. (2005). Self-initiated foreign experience as accelerated development: Influences of gender. Journal of World Business, 40(4), 421-431.

Ren, H., Bolino, M. C., Shaffer, M. A. \& Kraimer, M. L. (2012). The influence of job demands and resources on repatriate career satisfaction: A relative deprivation perspective. Journal of World Business, 48, 149159

Richardson, J. \& Mallon, M. (2005). Career interrupted? The case of the self-directed expatriate. Journal of World Business, 40(4), 409-420.

Sanchez, J. I., Spector, P. E. \& Cooper, C. L. (2000). Adapting to a boundaryless world: A developmental expatriate model. The Academy of Management Executive, 14(2), 96-106.

Selmer, J. \& Lauring, J. (2010). Self-initiated academic expatriates: Inherent demographics and reasons to expatriate. European Management Review, 7(3), 169-179.

Sriskandarajah, D. \& Drew, C. (2006). Brits abroad. Mapping the scale and nature of British emigration. London: ippr.

Suutari, V. \& Brewster, C. (2000). Making their own way: Through self-initiated foreign assignment, 417-436.

Sveningsson, S. \& Alvesson, M. (2003). Managing managerial identities: Organizational fragmentation, discourse and identity struggle. Human relations, 56(10), 1163-1193.

Tajfel, H. \& Turner, J. C. (1979). An integrative theory of intergroup conflict. The Social Psychology of Intergroup Relations, 33, 47.

Terry, D. J., Hogg, M. A. \& White, K. M. (1999). The theory of planned behaviour: self-identity, social identity and group norms. British Journal of Social Psychology, 38(3), 225-244. 
Tharenou, P. \& Caulfield, N. (2010). Will I stay or will I go? Explaining repatriation by self-initiated expatriates. Academy of Management Journal, 53(5), 1009-1028.

Tharenou, P. (2010). Identity and global mobility. In The Psychology of Global Mobility (pp. 105-123). Springer New York.

The Star Online. Leveraging on Malaysian Diaspora. (2012, March 16).

Thorn, K. (2009). The relative importance of motives for international self-initiated mobility. Career Development International, 14(5), 441-464.

Torkington, K. (2010). Defining lifestyle migration. Dos Algarves, 19, 99-111.

Tuan, Y. F. (1977). Space and place: The perspective of experience. Retrieved from http://books.google.com.my/books?hl=en\&lr=\&id=M9SLfxpkscgC\&oi=fnd\&pg=PR5\&dq=tuan\&ots=V 4vcxv45He\&sig=ke8iMORK4P7IEvQ5hSZyN6LoC-Y.

Yusliza, M. Y. (2011). Addressing the Brain Drain of Malaysian Professionals to Developed Countries, Workshop on Transforming Malaysia: Ideas for the Next Decade, 28 - 29 September, Institute of Southeast Asian Studies, Singapore. 